\title{
Carbon Sequestration as Influenced by Cropping Practices: A Review
}

\begin{abstract}
Global warming has been a serious concern in recent times with regards to declining productivity which will soon emerge as a major challenge for future of agricultural systems. The major contributors to the global warming are the atmospheric carbon dioxide, methane and nitrous oxide. Agriculture has the vast potential for the carbon sequestration. Certain modifications in agricultural practices can efficiently reduce atmospheric carbon dioxide. In this paper the role of conservation tillage, cropping pattern including crop rotation and intercropping, nutrient management, livestock management in agriculture, cover crops in sequestering the atmospheric carbon dioxide has been reviewed along with evidences of the work carried out across the nations.
\end{abstract}

Key words: Carbon sequestration, Conservation tillage, Cover crops, Cropping pattern, Global warming, Livestock.

Global warming is causing a serious concern for the scientists all over the world. The interest in the field is deepening with time. Before the Industrial Revolution started in the mid-1700s, the global average amount of carbon dioxide was about 280 ppm and it was reported to be 409.8 ppm in 2019 (Lindsey, 2020). The rising levels of carbon dioxide and the consequent increase in the temperature can cause a serious threat to the infrastructure, human health, businesses etc. Climate change will impact the economy of all the countries negatively; however, the developing and underdeveloped countries of South Asia and Sub Saharan Africa are at greater risk. According to a simulation study (GTAP INT calculations), it is concluded that with each degree rise in temperature, there is increase in the net negative loss of GDP per year, however, this loss is more for the countries located in South Asia and Africa (Kompas et al, 2018). The losses in the long run varies from the -0.383 per cent/ year for Finland and -0.885 per cent/ year to -17.437 per cent/ year for Sri Lanka to -26.556 per cent/ year for Togo with rise of $4^{\circ} \mathrm{C}$ in temperature. (Kompas et al, 2018). The change in climate can also influence the human health both directly and indirectly. The effect of heat stress is direct one whereas, the changes in the nature of vectors and pathogens vis a vis susceptibility of the human will increase the susceptibility. Agriculture is an important sector where the impact of rising carbon di oxide can take heavy toll. Increase in the carbon dioxide concentration will increase the net rate of photosynthesis (Cure and Acock 1986, Allen et al. 1987). However, the increase in carbon dioxide levels will also lead to decrease in the transpiration due to closure of stomata which can interrupt the growth and development. The reduction in transpiration can be up to 30 per cent in certain crops (Kimball, 1983). Rise in carbon dioxide level will also be accompanied by the rise in average temperature which may have both direct and indirect effect on the crop yield. Rising temperatures and changes in rainfall patterns
${ }^{1}$ Gobind Ballabh Pant University of Agriculture and Technology, Pantnagar-263 153, Uttarakhand, India.

${ }^{2}$ Himgiri Zee University, Dehradun-248 197, Uttarakhand, India.

Corresponding Author: Alok Singh Jayara, Gobind Ballabh Pant University of Agriculture and Technology, Pantnagar-263 153, Uttarakhand, India. Email: aloksingh.jayara@gmail.com

How to cite this article: Jayara, A.S., Pandey, S. and Bhatt, M.K. (2022). Carbon Sequestration as Influenced by Cropping Practices: A Review. Agricultural Reviews. DOI: 10.18805/ag.R-2253.

Submitted: 06-05-2021 Accepted: 08-12-2021 Online: 21-01-2022

have direct effects on crop yields, as well as indirect effects through changes in irrigation water availability (Nelson et al. 2009). A search was carried out for the effect of climate change under various models on the yield of important crops over different locations and are presented in Table 1.

Rise in $\mathrm{CO}_{2}$ levels in atmosphere has positive influence on the photosynthesis by the plant. The increase is higher in the C3 plants when compared to CAM and $\mathrm{C}_{4}$ plants as the photorespiration which operates in $C_{3}$ plants is suppressed. The increase in net photosynthesis in $\mathrm{C}_{3}$ species has been reported as high as $50-100 \%$ when $\mathrm{CO}_{2}$ concentration doubles compared to $10 \%$ in $\mathrm{C} 4$ species (Unsworth and Hogsett, 1996) and photosynthesis in $\mathrm{C}_{3}$ plants increases up to 800-1000 ppm (Amthor, 2001). However, rise in $\mathrm{CO}_{2}$ levels causes greenhouse effect leading to an increase in temperature. The rise in temperature leads to the reduction in transpiration leading to closure of stomata. The rise in temperature after the flowering/panicle initiation in crops lead to the increase in growth rate. This reduces the total duration of the grain filling leading to the reduction in the yields. Thus, it becomes important to reduce or retain the atmospheric $\mathrm{CO}_{2}$ concentration to limit the global warming. 
Carbon sequestration is a process of capturing and storing atmospheric $\mathrm{CO}_{2}$ in solid or liquid form through natural or artificial process. SOC is classified into three fractions, according to their rate of mineralization or turnover. Three major organic carbon pools are represented below (Table 2).

Plants serve as an important medium of fixing atmospheric carbon through the process of photosynthesis. This fixed carbon is utilized for the formation of leaves, stems, roots etc. which later get added to soil as litter and thus, increases the soil carbon content. However, the agricultural practices in the form of tillage, nutrient management, irrigation management and cropping pattern also lead to the loss of the soil organic carbon. It has been estimated that 30-50 per cent of SOC has been lost after the initialization of agriculture (Kucharik et al. 2001). Modifying agricultural practices can be an effective measure to enhance the carbon sequestration in soil. Approximately $12 \%$ of soil C is held in cultivated soils (Schlesinger, 1991), which cover around $35 \%$ of the terrestrial land area of the planet (Betts et al. 2007). In agriculture, carbon sequestration can also be enhanced through reducing the loss of soil organic and inorganic carbon from soil to the atmosphere. It has been suggested that, relative to other negative emission options, soil $\mathrm{C}$ sequestration may offer one of the least expensive and most readily implementable near-term options (NASEM, 2018). Increasing the soil carbon pool will also have multiplier effect on the soil fertility, better soil structure and reduced erosion.

\section{Conservation tillage}

Conservation tillage refers to the practices of maintaining at least $30 \%$ of the crop residue on the soil surface varies with the type of tillage, the extreme form as zero tillage. The mechanisms responsible for promotion of SOC sequestration through conservation tillage are moderation of temperature regimes, changes in soil moisture regimes and erosion control, increases the diversity and activity of soil fauna e.g. earthworms, reducing soil and water loss by protecting against rain drops, enhancing stable aggregates, soil aggradations and reduces degradation (Lal and Kimble, 1997). No till studies has shown that there is increase in the SOC in the shallow depths and lesser SOC in deeper layers when compared to the conventional tillage and equivalent for both when whole soil profile is considered owing to reduced temperature regimes, increasing soil strength and bulk density under no till conditions (Baker et al., 2007; Yang et al., 2014). Similar results were reported by Deen and Kataki (2003) where higher SOC was reported with zero tillage in $0-20 \mathrm{~cm}$ depth when compared to spring and fall

Table 1: Effect of climate change under various models on the yield of important crops over different locations.

\begin{tabular}{|c|c|c|c|c|}
\hline Crop & $\begin{array}{l}\text { Location of } \\
\text { study site }\end{array}$ & Changes simulated & $\begin{array}{l}\text { Change (\%) } \\
\text { in yield }\end{array}$ & Source \\
\hline \multirow[t]{5}{*}{ Wheat } & Iran & Global temp change 1.1 to $3.8^{\circ} \mathrm{C}$ & -1 to -37 & Valizadeh et al. 2014 \\
\hline & \multirow[t]{2}{*}{ South Australia } & $\mathrm{CO}_{2}$ change $51-125 \%$; Local rainfall & -13.5 to -32 & Luo et al. 2005 \\
\hline & & changes in growing season $(-8.6$ to $+4.6 \%)$ & -41 to +6.3 & Seino, 1995 (as cited in Luo et al. 2005) \\
\hline & Japan & NA & -30 to +7 & Delecolle et al. 1995 (as cited in Luo \\
\hline & France & NA & & et al. 2005) \\
\hline \multirow[t]{6}{*}{ Rice } & Egypt & RCP 8.5 (Irrigated condition) & -19 & Pepijn et al. 2017 \\
\hline & East Africa & RCP 8.5 (Irrigated condition) & -20 & $\ldots \ldots \ldots$. do $\ldots \ldots \ldots$ \\
\hline & West Africa & RCP 8.5 (Irrigated condition) & -20 & $\ldots \ldots \ldots$ do $\ldots \ldots \ldots$ \\
\hline & Malaysia & $1 \%$ rise in temperature & -3.44 & Alam et al. (2014) \\
\hline & Phillipines & $1^{\circ} \mathrm{C}$ increase & -10 & Peng et al. (2004) \\
\hline & India & Each $1^{\circ} \mathrm{C}$ increase in temp & -7.2 & Krishnan et al. 2007 \\
\hline \multirow[t]{8}{*}{ Maize } & lowa State & $1^{\circ} \mathrm{C}$ increase & -10 & Ummenhofer et al. 2015 \\
\hline & (USA) & $1^{\circ} \mathrm{C}$ increase & -15 & Ummenhofer et al. 2015 \\
\hline & SE Australia & RCP 8.5 & -3.8 & Petersen, 2019 \\
\hline & USA & $\mathrm{RCP} 4.5$ & -1.8 & Petersen, 2019 \\
\hline & USA & & -3.3 to -5.9 & Luhunga, 2017 \\
\hline & Tanzania & $\mathrm{RCP} 4.5$ & -10.2 to -11.2 & Luhunga, 2017 \\
\hline & Tanzania & RCP 8.5 & -20 to -40 & Singh et al. 2010 \\
\hline & India & $5^{\circ} \mathrm{C}$ increase & & \\
\hline
\end{tabular}

Table 2: Major functional pool, their composition, percent share of total and turnover time (Lal and Kimble, 1997; Stavi and Lal, 2010).

\begin{tabular}{llcc}
\hline Type of fraction & Composition & Per cent share (\%) & Turnover time (year) \\
\hline Labile/ Active & Soluble carbohydrates, exocellular enzymes and microbial biomass & $15-20$ & $0.2-1.4$ \\
Intermediate/ Slow & Particulate organic matter & $20-40$ & $8-50$ \\
Recalcitrant/ Passive & Humic and fulvic acids; organo-mineral complex & $60-70$ & $400-2200$ \\
\hline
\end{tabular}


season tillage. However, highest SOC was reported with no till followed by chisel plough and MB plough in $0-75 \mathrm{~cm}$ soil depth (Olson et al. 2013). No till and reduced till had significantly higher SOC sequestration when compared to conventional tillage, with increasing trend towards zero till (Alvarez, 2005). Soil respiration plays a key role in determining the carbon balance ( $\mathrm{Li}$ et al. 2010). Soil aggregates has key role in the conservation of soil organic carbon. Tilling of soil leads to losses of SOC as cultivation breaks up the soil and exposes organic matter previously protected within soil macro aggregates to microbial decay. No till always protect the $C$ mineralization cannot be generalized as it depends on the soil climatic conditions, amount and location of crop residues and soil organic matter and higher $\mathrm{CO}_{2}$ emission has also been reported with not till than conventional tillage (Yang et al., 2014; Rong-Kan et al., 2020). The beneficial impact of the reduced tillage in terms of carbon sequestration is realized with the residue incorporation. The combination of reduced tillage and residue incorporation is the practice of conservation tillage. No tillage with straw mulching reported highest net ecosystem carbon balance (NCF) followed by rotatory tillage with straw incorporation and chisel plough with straw incorporation whereas the conventional moldboard ploughing tillage without crop straw reported negative NCF in rainfed winter wheat-summer maize cropping system (Lu et al. 2018). Long term No till with straw incorporation reported highest SOC sequestration as it improves the aggregation of macro-aggregate (Rong-Kan et al., 2020). In the residue management, it was also observed that the type of straw also influence the carbon sequestration. Basch et al. 2010 reported that under no till system, the significantly higher SOC was reported with the $5000 \mathrm{~kg} /$ ha wheat straw, when compared with $2500 \mathrm{~kg} / \mathrm{ha}$ wheat straw and $750 \mathrm{~kg} /$ ha chickpea residue. The difference is attributed to the higher $\mathrm{C}$ : $\mathrm{N}$ ratio in wheat when compared to chickpea. Similarly, Cha-un et al. 2015 studied the crop rotation with residue incorporation for 4 year period and concluded that Ricerice had highest SOC level when compared to Corn-rice and Sweet sorghum-rice which was attributed to higher C: $\mathrm{N}$ ratio present in rice stubbles. Powlson et al. 2014 and Baker et al. 2007 reported that the majority of studies on no-till and conservation tillage primarily demonstrate differences in carbon concentrations at the soil surface, while ignoring lower depths where more aggressive tillage systems, such as moldboard plowing, may actually be relocating carbon.

\section{Cropping pattern}

Cropping pattern refers to the arrangement of crops over a unit area in spatial and temporal context referred as inter/ mixed cropping and crop rotation, respectively. The crop which adds more biomass (both above ground and below ground) is effective in carbon sequestration. The photosynthates in leaves are transported to the roots and are also secreted in the soils in the form of various organic compounds. Cropping pattern can be effective in carbon sequestration as cropped land occupies 35 per cent of the total global area. Shrestha et al. 2013 reported that wheatoilseed-pulses recorded highest SOC level in both $0-7.5 \mathrm{~cm}$ and $0-15 \mathrm{~cm}$ fallow-crop-crop rotation (crop includes canola, wheat and pulses). Njaimwe et al. 2016 reported that maizeoats-maize rotation enhanced the carbon sequestration as compared to maize-wheat-maize and maize-fallow-maize rotation. In the Indo-Gangetic plains of India, Rice-wheatmungbean system resulted in 6 per cent increase in SOC and 85 per cent increase in soil microbial biomass carbon as compared to conventional Rice-wheat cropping system (Ghosh et al. 2012). Lötjönen and Ollikainen (2017) conducted an analytical model study on cereal monoculture and cereal-legume rotation (clover based rotation) and reported that latter led to average decrease in the GHG emission per year by $4705 \mathrm{~kg} \mathrm{CO}$-eq/ha (31\%). Pikula and Rutkowska (2014) reported that crop rotation without legumes reported drop of SOC to 0.61 per cent whereas, the rotation with legumes (clover-grass mixture) reported the highest value of SOC up to 0.79 per cent. Drinkwater et al. 1998 reported that the corn-soybean rotation system had the greatest productivity and returned the largest crop residues to the soil compared to monoculture of corn or soybean.

Intercropping is practiced by the farmers for the efficient utilization of resources, harnessing complementary interaction between the component crops and higher yields as compared to single cropping. The crops intercropped produce more biomass (both above ground and below ground) which leads to the more fixation of carbon in soil. Hu et al. 2015 reported that wheat and maize intercropping emitted 10 per cent lower carbon than sole maize cropping. Ferreira et al. (2019) reported that the intercropping systems along with minimum soil tillage were more effective in maintaining and sometimes increasing the levels and stocks of SOC as compared with native vegetation.

Agro forestry is the other system which is effective in carbon sequestration. In a modeling study in the seven districts of Central Plateau and hill agro climatic zone in India, it was estimated that total carbon sequestered was 2.141 MtC (Rizvi et al. 2019). Winans et al. 2016 reported that tree based intercropping (TBI) system had 33-36 per cent more $C$ storage than adjacent non-TBI system. In addition to $C$ sequestration, agroforestry also increases the net income of farm and changes the microclimate of the crop field which has positive influence on crop growth and development.

\section{Nutrient management}

Soil acts as a store house of the nutrients. Good nutrient management is essential for higher yields, which will spare the additional use of land in agriculture. Crop plants use these nutrients for their growth and development and accumulate biomass. The potential biomass in the crop plants is determined by the solar radiation and consequent 
photosynthesis, however, the realization of potential is dependent of the nutrient supply. This biomass (both above ground and below ground) when incorporated in to the soil leads to enhancement of the SOC status. In addition, the better nutrient status of the soil also encourages the growth of the various other plants and micro-organisms which are contributor of the organic carbon. The nutrient management and soil carbon sequestration can be achieved by knowing the source of nutrient, time and method of application and reducing the nutrient loss from soil e.g. denitrification in form of nitrous oxide from the rice fields ultimately lead to the global warming. The other forms in which it can be conserved are reducing leaching losses and volatilization losses. Nutrients are supplied through both organic and inorganic sources. The management of nutrients combining both organic and inorganic sources is found to be more effective in carbon sequestration. Therefore, nutrient management in agriculture can play an important role in the carbon sequestration. Nutrients are classified into primary, secondary and micro nutrients. It is reported that to sequester $10 \mathrm{Mg} \mathrm{C}$ in crop residues, $833 \mathrm{~kg}$ of Nitrogen, $200 \mathrm{~kg}$ of phosphorus and 143 $\mathrm{kg}$ of sulphur is required (Hussain et al. 2021). Carbon stocks of the soils were higher when organic inputs were combined with mineral fertilizer, compared to only organic inputs or only mineral fertilizer (Hijbeek, 2019; Trivedi et al., 2020). Zhang et al. 2012 reported that application of organic amendments for 25-28 years increased SOC by 7-45 per cent when compared to mineral fertilization.

Increasing nutrient use efficiency is essential to offset the release of Green house gases in agriculture through their use. Time and method of application of nutrient fertilizer have a larger role in determining the nutrient use efficiency. Agriculture contributes 70-90 per cent of $\mathrm{N}_{2} \mathrm{O}$ emissions mostly from the nitrogen fertilizers which can be prevented by the site specific nutrient management as the total nutrient to be applied will be reduced, thus reducing the $\mathrm{N}$ loss in form of volatilization, runoff and leaching loss (Richards et al. 2015). Site specific adaptive research is needed to identify recommended management practices (RMPs) that optimize soil $\mathrm{N}$ use efficiency while improving crop yield and $\mathrm{C}$ sequestration thereby curbing greenhouse gas (GHG) emissions (Christopher and Lal, 2007). Practices that improve $\mathrm{N}$ use efficiency includes adjusting application rates based on precise estimation of crop needs (e.g., precision farming); using slow-or controlled-release fertilizer forms or nitrification inhibitors (which slow the microbial processes leading to $\mathrm{N}_{2} \mathrm{O}$ formation); applying $\mathrm{N}$ when least susceptible to loss, often just prior to plant uptake (improved timing); placing the $\mathrm{N}$ more precisely into the soil to make it more accessible to crops roots; or avoiding $\mathrm{N}$ applications in excess of immediate plant requirements (Smith et al. 2007).

\section{Cover cropping}

The production of higher biomass under cover crops and its subsequent addition to the soil leads to the enrichment of SOC in soil. The roots of these crops add the organic matter which promotes the aggregate formation and thus conserves the soil carbon. The reduction of temperature under cover crops lead to the reduced decomposition, thus, loss of SOC is prevented. Adding organic matter through crop and other residues moderate soil temperature, which further reduces the rate of carbon loss (Melillo et al. 2017). The associated increase of SOC with the cover crops is also attributed to the reduced erosion. A regression analysis revealed that changes in SOC from cover cropping is correlated with improvements in soil quality, specifically decreased runoff and erosion and increased amount of mineralizable carbon, mineralizable nitrogen and soil nitrogen (Jian et al. 2020). McDowell, 2019 reported that the rye cover crop and cover crop mix increased the percentage of macro aggregates by about 4.1 to 5.1 per cent and total particulate organic matter (POM), the labile or easy to degrade organic matter, by 14 per cent as compared to control. Poeplau and Don, 2015 concluded that the cover crop treatments had a significantly higher SOC stock than the reference croplands. Jian et al. 2020 in a meta analysis and regression studies concluded that cover cropping increases SOC in near surface soils by an average of 15.5 per cent. Whereas medium-textured soils had highest SOC stocks (overall means of $39 \mathrm{Mg} \mathrm{ha}^{-1}$ with and $37 \mathrm{Mg} \mathrm{ha}^{-1}$ without cover crops), fine-textured soils showed the greatest increase in SOC after the inclusion of cover crops (mean change of $39.5 \%)$. Coarse-textured $(11.4 \%)$ and medium-textured soils $(10.3 \%)$ had comparatively smaller changes in SOC, while soils in temperate climates had greater changes $(18.7 \%)$ than those in tropical climates (7.2\%). Sainju et al. (2006) also reported that SOC increased by $6-8 \%$ with cover crops at 0 to $10 \mathrm{~cm}$ and by $0.4 \%$ with rye in monoculture and $3 \%$ with vetch and rye in biculture at $0-30 \mathrm{~cm}$.

\section{Inclusion of livestock in agriculture systems}

Livestock management has become an essential component of agriculture systems. This is more important for the countries like India where majority of farmers are having marginal land holding owing to more profitability per unit land area. In some developing countries, livestock contributes 50-80 per cent of GDP (World Bank, 2007). In terms of SOC sequestration, livestock is an essential source of organic matter, grassland management is essential for conserving SOC and inclusion of ley farming can add to the more biomass and thus, higher SOC will be added. Livestock themselves release large amount of GHG due to enteric fermentation. Improved feeding practices, use of specific dietary additives, long term changes in management and animal breeding can reduce the $\mathrm{CH}_{4}$ and $\mathrm{N}_{2} \mathrm{O}$ emissions (Smith et al. 2007). Grasses due to their high density of root biomass and quick regenerative ability improve the aggregate formation and add to SOC sequestration. Conversion of land use from grassland to farmland leads to loss of soil organic carbon.

In grassland systems, there is balance between the above ground biomass, grazing and belowground root biomass. The grazing by the cattle leads to the pruning back of green biomass, thus, the equivalent belowground root 
biomass dies off leading to the addition of SOC. After certain period remaining shoot and root rejuvenates in to the grassland. Poor grassland management disrupts this cycle. Removal of large amounts of aboveground biomass, continuous heavy stocking rates and other poor grazing management practices are important human-controlled factors that influence grassland production and have led to the depletion of soil carbon stocks (Conant, 2010). The composition of the species in the grassland also influences the SOC sequestration. The restoration of grassland with high plant diversity may greatly increase carbon capture and storage rates on degraded and abandoned agricultural lands (Yang et al. 2019).

While grassland management is perennial activity, ley farming provides opportunity to include SOC enriching forage species in between the annual crop rotations. The pasture phase during the crop rotation provides inputs of organic matter and has reduced tillage, with less erosion, fertilizer and herbicides application (Edwards et al. 2019). Ley farming is a viable alternative to burning crop residues to clear a field, which is a common practice in Africa and causes considerable loss of SOC (Jarecki and Lal, 2003). Lugato et al. (2014) reported that highest SOC sequestration was when the land use is changed from arable to grassland, followed by ley crop in rotation and cover crops and these both were superior over residue management and straw incorporation. Prade et al. (2017) observed that under modified scenario (including a year of grass rotation in the four year cereal based rotation leaving all straw in the field and pig manure as part of fertilizer requirement), the SOC reached 5.1 per cent after 140 years whereas, it was only 3 per cent in current scenario (similar to modified scenario except grass in rotation).

\section{Challenges and Opportunities}

Globally, agricultural $\mathrm{CH}_{4}$ and $\mathrm{N}_{2} \mathrm{O}$ emissions have increased by nearly $17 \%$ from 1990 to 2005 , an average annual emission increase of about $60 \mathrm{MtCO}_{2}$-eq $\mathrm{yr}^{-1}$ (Smith et al. 2007). The global technical mitigation potential from agriculture (excluding fossil fuel offsets from biomass) by 2030 is estimated to be $\sim 5500-6,000 \mathrm{Mt} \mathrm{CO}_{2}$-eq $\mathrm{yr}^{-1}$ (medium agreement, medium evidence) (Smith et al. 2007).

There are various challenges to the carbon sequestration in agriculture. The foremost challenge is to measure the amount of amount of $C$ sequestered in the soil. The addition and removal of the carbon in soil is a continuous process. It is also difficult to measure if, the carbon sequestered in the soil is due the management practices followed. Carbon sequestered in the soil is amenable to the immediate loss. It can only be held if the soil is not disturbed for a longer period. Global penetrance of conventional tillage rather than minimum and zero tillage is another challenge. Worldwide area under zero-tillage in 1999 was approximately $50 \mathrm{~m}$ ha, representing $3.5 \%$ of total arable land (Smith et al. 2007).

According to the IPCC agricultural soils have the potential of sequestering up to 1.2 billion tonnes of carbon per year. Mineralization of only $10 \%$ of the soil organic carbon pool globally is believed to be equivalent to about 30 years of anthropogenic emissions (Abdullahi et al. 2018). This becomes more important when 30 per cent of the total geographical area of the world is under agriculture systems. The carbon markets if extended to the agriculture can make carbon sequestration in agriculture more attractive. The combine value of markets for green house gases (GHG) emission reduction increased to more that US $\$ 100$ billion, however, agriculture has largely been excluded from formal and informal carbon markets (De Pinto et al. 2010). All the activities in the agriculture are having the complementary benefits in form of increased fertility and nutrient status, soil and moisture conservation, improved physical and chemical properties of soil and will lead to the sustainable increase in the agriculture productivity. Reducing soil disturbance is also fuel efficient. However, it is to be ensured that major work is to be carried out on the measuring parameters of sequestered carbon, permanence of the sequestered carbon and developing favorable policy environment for it.

\section{CONCLUSION}

Soil carbon sequestration involves transferring atmospheric carbon into the soil via plant photosynthesis and keeping those soil-based carbon pools protected as effectively as possible from microbial activity that will release the carbon back to the air. There are agricultural management practices that show promise for restoring soils and sequestering a very significant portion of atmospheric carbon. The need for drawdown strategies is increasingly urgent and soil carbon sequestration through agriculture warrants far greater attention from policymakers, climate negotiators, farmers, ranchers and scientists. Most, if not all, of the management regimes that promote carbon sequestration also improve soil aggregation, water retention, soil fertility and food security.

\section{REFERENCES}

Abdullahi, C.A., Siwar C., Mohamad, S., Isahak, A. (2018). Carbon Sequestration in Soils: The Opportunities and challenges. In "Carbon Capture, Utilization and Sequestration. (Ed: Agrawal, R.K.). IntechOpen.

Alam, M.M., Talib, B., Siwar, C., Toriman, M.E. (2014). Impacts of climate change on paddy production in Malaysia: Micro study on IADA at North West Selangor. Research Journal of Environmental and Earth Sciences. 6: 251-258.

Allen, L.H. Jr, Boote, K.J., Jones, J.W., Jones, P.H., Valle, R.R., Acock, B., Rogers, H.H., Dahlman, RC.(1987). Response of vegetation to rising carbon dioxide: Photosynthesis, biomass and seed yield of soyybean. Global Biogeochemical Cycles. 1: 1-14.

Alvarez, R. (2005). A review of nitrogen fertilizer and conservation tillage effects on soil organic carbon storage. Soil Use and Management. 21: 38-52.

Amthor, J.S. (2001). Effects of atmospheric $\mathrm{CO}_{2}$ on wheat yield: review of results from experiments using various approaches to control $\mathrm{CO}_{2}$ concentration. Field Crop Research. 73: 1-34. 
Baker, J.M., Ochsner, T.E., Venterea, R.T., Griffis.T.J. 2007. Tillage and soil carbon sequestration Agriculture, Ecosystems and Environment. 118(1-4): 1-5. e 4(8): 678-683.

Basch, G., Carvalho, M., Barros, J.F.C., Calado, J.M.G. (2010).The importance of crop residue management for carbon sequestration under no-till.Congreso Europeo de Agricultura de Conservación Madrid.

Betts, R.A., Falloon, P.D., Goldewijk, K.K., Ramankutty, N. (2007). Biogeophysical effects of land use on climate: Model simulations of radiative forcing and large-scale temperature change.Agricultural and Forest Meteorolgy. 142(2): 216-233.

Cha-un, N., Chidthaisong, A., Towprayoon, S. (2015). Short-term and long-term soil carbon sequestration in rice field with energy crop rotation. Journal of Sustainable Energy and Environment. 6(4): 97-105.

Christopher, S.F. and Lal, R. (2007). Nitrogen management affects carbon sequestration in north american cropland soils. Critical Reviews in Plant Sciences. 26(1): 45-64.

Conant, R.T. (2010). Challenges and opportunities for carbon sequestration in grassland systems: A technical report on grassland management and climate change mitigation. FAO, Rome.

Cure, J.D. and Acock, B. (1986). Crop responses to carbon dioxide doubling: A literature survey. Agriculture and Forest Meteorology. 38: 127-145.

Deen, W. and Kataki, P.K. (2003). Carbon sequestration in a longterm conventional versus conservation tillage experiment. Soil and Tillage Research. 74: 143-150.

Delecolle, R., Ruget, F., Ripoche, D. (1995). Possible Effects of Climate Change on Wheat and Maize Crop in France. In: Climate Change and Agriculture: Analysis of Potential International Impacts, [(Ed) Rosenzwieg, C., Ritchie, J.T., Jones, J.W.]. ASA, Special Publication, Madison. 59: 241-257.

DePinto, A., Magalhaes, M., Ringler, C. (2010). Potential of carbon markets for small farmers $-A$ literature review. Internal Food Policy Research Institute, Environment and Production Technology Division, Discussion Paper 01004.

Edwards, T., Howieson, J., Nutt, B. et al. (2019). A ley-farming system for marginal lands based upon a self-regenerating perennial pasture legume. Agronomy for Sustainable Development. 39: 13.

Ferreira, M.S.M., Tamie, O.A., Sá, M.E., Lima, N.J.C., Senna de, O.T. (2019). Combined effect of intercropping and minimum tillage on soil carbon sequestration and organic matter pools in the semiarid region of Brazil. Soil Research. 57(3): 266-275.

Ghosh, P., Venkatesh, M., Hazra, K. and Kumar N. (2012). Long term effect of pulses and nutrient management of soil organic carbon dynamics and sustainability on an inceptisol of Indi- Gangetic plains of India. Experimental Agriculture. 48(4): 473-487.

Hijbeek, R., Van Loon, M.P., Van Ittersum M.K. (2019). Fertiliser Use and Soil Carbon Sequestration: Opportunities and Trade-offs. CCAFS Working Paper no. 264. Wageningen, the Netherlands: CGIAR Research Program on Climate Change, Agriculture and Food Security (CCAFS).
Hu, F., Chai, Q., Yu, A., Yin, W., Cui, H. et al. (2015). Less carbon emissions of wheat- maize intercropping under reduced tillage in arid areas. Agronomy for Sustainable Development. 35 (2): 701-711.

Hussain, S., Hussain, S., Guo, R., Sarwar, M., Ren, X., Krstic, D., Aslam, Z., Zulifqar, U., Rauf, A., Hano, C., et al. (2021). Carbon Sequestration to Avoid Soil Degradation: A Review on the Role of Conservation Tillage. Plants. 10: 2001.

Jarecki, M.K. and Lal, R. (2003). Crop management for soil carbon sequestration. Critical Review in Plant Sciences. 22(6): 471-502.

Jian, J., Du, X., Reiter, M.S., Stewart, D.R. (2020). A meta-analysis of global cropland soil carbon changes due to cover cropping. Soil Biology and Biochemistry. 143: 107735.

Kimball, B.A. (1983). Carbon dioxide and agricultural yields: An assemblage and analyses of 430 prior observations. Agronomy Journal. 7: 779-788.

Kompas, T., Pham, V.H., Che, T.N. (2018). The effects of climate change on GDP by country and the global economic gains from complying with the Paris Climate Accord. Earth's Future. 6: 1153-1173.

Krishnan, P., Swain, D.K., Chandra Bhaskar, B., Nayak, S. K., Dash, R.N. (2007). Impact of elevated $\mathrm{CO}_{2}$ and temperature on rice yield and methods of adaptation as evaluated by crop simulation studies. Agriculture, Ecosystems and Environment. 122: 233-242.

Kucharik, C.J., Brye, K.R., Norman, J.M., Foley, J.A., Gower, S.T., Bundy, L.G. (2001). Measurements and modeling of carbon and nitrogen cycling in agroecosystems of southern Wisconsin: potential for SOC sequestration during the next 50 years. Ecosystems. 4(3): 237-258.

Lal, R. and Kimble, J.M. (1997). Conservation tillage for carbon sequestration. Nutrient Cycling in Agroecosystems 49: 243-253.

Li, X.D., Fu, H., Guo, D., Li, X.D., Wan, C.G. (2010). Partitioning soil respiration and assessing the carbon balance in a Setaria italica (L.) beauv. cropland on the Loess Plateau, Northern China. Soil Biology and Biochemistry. 42(2): 337-346.

Lindsey, R. (2020). Climate Change: Atmospheric Carbon di oxide. Climate.gov.

Lötjönen, S. and Ollikainen, M. (2017). Does crop rotation with legumes provide an efficient means to reduce nutrient loads and GHG emissions? Review of Agricultural Food and Environmental Studies. 98: 283-312.

Lu, X., Lu, X. and Liao, Y. (2018). Conservation tillage increases carbon sequestration of winter wheat-summer maize farmland on Loess Plateau in China. PLoS ONE. 13(9): e0199846.

Lugato, E., Bampa, F., Panagos, P., Montanarella, L. and Jones, A. (2014). Potential carbon sequestration of European arable soils estimated by modelling a comprehensive set of management practices. Global Change Biology. 20(11): 3557-3567.

Luhunga, P.M. (2017). Assessment of the impacts of climate change on maize production in the southern and western highlands sub-agro ecological zones of Tanzania. Frontiers in Environmental Sciences. 5: 51. 
Luo, Q., William, B., Martin, W., Brett, B. (2005).Potential impact of climate change on wheat yield in South Australia. Agriculture and Forest Meteorology. 132: 273-285.

McDowell, J. (2019). Cover Crops and Carbon Sequestration: Benefits to the Producer and the Planet. Crop watch.https:// cropwatch.unl.edu/2019/cover-crops-and-carbonsequestration benefits-producer-and-planet.

Melillo, J.M., Frey, S.D., DeAngelis, K.M., Werner, W.J., Bernard, M.J., Bowles, F.P., Pold, G., Knorr, M.A. and Grandy, A.S. (2017). Long-term pattern and magnitude of soil carbon feedback to the climate system in a warming world. Science. 358: 101-105.

NASEM (National Academies of Sciences, Engineering and Medicine). (2018). Negative Emissions Technologies and Reliable Sequestration: A Research Agenda. The National Academies Press. Washington, DC.

Nelson, G.C., Rosegrant, M.W., Koo, J., Robertson, R., Sulser, T., Zhu, T., Lee, D. (2009). Climate Change Impact on Agriculture and Costs of Adaptation. IFPRI, Washington D.C.

Njaimwe, A.N., Mnkeni, P.N.S., Chiduza, C., Muchaonyerwa P. and Wakindiki, I..I.C. (2016). Tillage and crop rotation effects on carbon sequestration and aggregate stability in two contrasting soils at the Zanyokwe Irrigation Scheme, Eastern Cape province, South Africa. South African Journal of Plant and Science. 33(4): 317-324.

Olson, K.R., Ebelhar, S.A., Lang, J.M. (2013). Effects of 24 years of conservation tillage systems on soil organic carbon and soil productivity. Applied and Environmental Soil Science.2013: 617504.

Peng, S.B., Huang, J.L., Sheehy, J.E., Laza, R.C., Visperas, R.M., Zhong, X.H., Centeno, G.S., Khush,G.S., Cassman, K.G. (2004). Rice Yields Decline with Higher Night Temperature from Global Warming. Proceedings of the National Academy of Sciences of the United States of America. 101: 9971-9975.

Pepijn, A.J., Oort, V., Zwartt, S.J. (2017). Impacts of climate change on rice production in Africa and causes of simulated yield changes. Global Change Biology. 24: 1029-1045.

Petersen, L.K. (2019). Impact of climate change on 21st century crop yields in the U.S. Sustainable Agriculture for Climate change adaptation. Climate. 7(3): 40.

Pikula, D.and Rutkowska, A. (2014). Effect of leguminous crop and fertilization on soil organic carbon in 30-years field experiment. Plant, Soil Environment. 60(11): 507-551.

Poeplau, C. and Don, A. (2015). Carbon sequestration in agricultural soils via cultivation of cover crops- A meta-analysis. Agriculture, Ecosystem and Environment. 200: 33-41.

Powlson, D.S., C.M. Stirling, M.L. Jat, B.G. Gerard, C.A. Palm, P.A. Sanchez and K.G. Cassman. (2014). Limited potential of no-till agriculture for climate change mitigation. Nature Climate Change. 4(8): 678-683.

Prade, T., Katterer, T., Bjornsson, L. (2017). Including a one-year grass ley increases soil organic carbon and decreases greenhouse gas emissions from cereal-dominated rotations: A Swedish farm case study. Biosystems Engineering. 164: 200-212.
Richards, M. B., Butterbach-Bahl, K., Jat, M. L., Lipinski, B., OrtizMonasterio, I., Sapkota, T. (2015). Site-Specific Nutrient Management: Implementation guidance for policymakers and investors. Copenhagen, Denmark: CGIAR Research Program on Climate Change, Agriculture and Food Security (CCAFS).

Rizvi, R.H., Newaj, R, Chaturvedi, O.P., Prasad R., Handa, A.K., Alam B. (2019). Carbon sequestration and $\mathrm{CO}_{2}$ absorption by agroforestry systems: An assessment for Central Plateau and Hill region of India. Journal of Earth System Science.128: 56.

Rong-Kan, Z., Tian-Ma, S., Yue Liu, Q., Liu, B.Y., Virk, A. L., Ying Qi, J., Zhao, S., Lal, R., Zhang, H. L. (2020). Carbon sequestration and mineralization in soil aggregates under long-term conservation tillage in the North China Plain. Catena, 188: 104428.

Sainju, U.M., Singh, B.P., Wayne F.W., Wang, S. (2006). Carbon supply and storage in tilled and nontilled soils as influenced by cover crops and nitrogen fertilization. Journal of Environmental Quality. 35(4): 1507-1517.

Schlesinger, W. (1991). Biogeochemistry: An Analysis of Global Change. San Diego: Academic Press.

Seino, H. (1995). Implication of Climate Change for Crop Production in Japan. In: Climate Change and Agriculture: Analysis of Potential International Impacts. [(Ed.) Rosenzwieg, C., Ritchie, J.T., Jones, J.W.] ASA, Special Publication, Madison. 59: 293-306.

Shrestha, B.M., McConkey, B.G., Smith, W.N., Desjardins, R.L., Campbell, C.A., Grant, B.B., Miller, P.R. (2013). Effects of crop rotation, crop type and tillage on soil organic carbon in a semiarid climate. Canadian Journal of Soil Science. 93(1): 137-146.

Singh, S., Kattarkandi, B., Deka, S., Choudhary, R. (2010). Impact of climatic variability and climate change on maize productivity in north India. Current Advances in Agricultural Sciences. 2(1): 5-9.

Smith, P.D. Martino, Z., Cai, D., Gwary, H., Janzen, P., Kumar, B., McCarl, S., Ogle, F. O'Mara, C., Rice, B. Scholes and O. Sirotenko, O. (2007). Agriculture. In: Climate Change 2007: Mitigation. Contribution of Working Group III to the Fourth Assessment Report of the Intergovernmental Panel on Climate Change. [(Ed) B. Metz, B., Davidson, O.R., Bosch, P.R., Dave, R. and Meyer, L.A.], Cambridge University Press, Cambridge, United Kingdom and New York, NY, USA.

Stavi, I. and Lal, R. (2010). Challenges and opportunities of soil organic carbon sequestration in croplands. In: Lichtfouse E (ed) Sustain. Agri. Rev. Biodiversity, biofuels, agroforestry and conservation agriculture. Springer, Berlin. 5: 149-174.

Trivedi, A., Bhattacharya, R., Biswas, D.R., Das, S., Das, T.K., Mahapatra, P., Shahi, D.K., Sharma, C. (2020). Long-term impacts of integrated nutrient management with equivalent nutrient doses to mineral fertilization on soil organic carbon sequestration in a sub-tropical Alfisol of India.Carbon Management. 11(5): 483-497.

Ummenhofer, C.C., Xu, H., Twine, T.E., Girvetz, E.H., McCarthy, H.R., Chhetri, N., and Nicholas, K.A. (2015). How climate change affects extremes in maize and wheat yield in two cropping regions. Journal of Climate. 28(12): 4653-4687. 
Unsworth, M.H. and Hogsett, W.E. (1996). Combined Effects of Changing $\mathrm{CO}_{2}$, Temperature, UVB Radiation and $\mathrm{O}_{3}$ on Crop Growth. In: Global Climate Change and Agricultural Production, [(Ed: Bazzaz, F. and Sombroek, W.)]. FAO and John Wiley and Sons, New York: 171-198.

Valizadeh, J., Ziaei, S.M., Mazloumzadeh, S.M. (2014). Assessing climate change impact on wheat production (a case study). Journal of Saudi Society of Agricultural Science. 13: 107-115.

Winans, K.S., Whalen, J.K., Rivest, D., Cogliastro, A., Bradley, R.L. (2016). Carbon Sequestration and Carbon Markets for Tree-based Intercropping Systems in Southern Quebec, Canada. Atmosphere. 7: 17.
World Bank. (2007). Agriculture for Development. Washington, DC, 2007.

Yang, X., Drury, C.F., Wander, M.M. (2014). A wide view of no-tillage practices and soil organic carbon sequestration. Acta Agriculturae Scandinavica, Section B - Soil and Plant Science. 63(6): 523-530.

Yang, Y., Tilman, D., Furey, G. et al. (2019). Soil carbon sequestration accelerated by restoration of grassland biodiversity. Nature Communications. 10: 718.

Zhang, W., Xu, M., Wang, X. et al. (2012). Effects of organic amendments on soil carbon sequestration in paddy fields of subtropical China. Journal of Soils and Sediments. 12: 457-470. 